\title{
Students' Voice in Learning Style Assessment: The Innovative Learning Experiences Tool (ILE)
}

\author{
Nosisana Patricia Mkonto \\ Cape Peninsula University of Technology \\ South Africa
}

Received: Dec. 10, 2015 Accepted: April 10, 2016 Published: May 15, 2016

doi:10.5296/jse.v6i2.8700 URL: http://dx.doi.org/10.5296/jse.v6i2.8700

\begin{abstract}
Students who enter higher education have diverse learning needs, and higher education institutions need to provide for these needs. One way of dealing with this variety of learning needs is to empower students to play an active role in their own learning, by making them aware of their learning styles. Identifying learning styles is an important facet within the learning process. Assessing learning styles could provide students with an opportunity to be reflective, and interrogate how they learn. Students' learning styles can be assessed by using a learning styles assessment tool. The Innovative Learning Experiences (ILE) which was developed in this study, caters for the students' voice where students reflect on their past and present learning experiences.
\end{abstract}

Keywords: higher education, learning styles awareness, student voice, learning styles assessment tool, diverse learning needs, learning styles assessment. 


\section{Introduction}

Students who have diverse socio-cultural, personal characteristics and academic interests enrol at institutions of higher education in South Africa (Bone \& Reid, 2013). These students have different learning needs, and when the learning needs are not met, it results in high failure and attrition rates, especially among first year students at university (Bone and Reid 2013; Cekiso 2011). This has negative implications for the retention, progression and succession rates among students at higher education institutions.

There is thus a need for a paradigm shift in both teaching and learning approaches, which require lecturers to use a learner-centred approach that takes into account how students learn (Machemer \&Crawford, 2007).A learner-centred approach means that students take responsibility for their learning, and hence no longer receive information passively, and thus play an active role in their learning (Bezuidenhout \& Alt, 2011; Robotham, 1999). Research has shown that active learning yields positive results (Machemer \&Crawford, 2007; Robotham, 1999).In addition, students learn in different ways. Raising awareness regarding the diverse learning styles of students could prove invaluable within teaching and learning. Students who are aware of their learning styles can identify their strengths and weaknesses in learning, and are able to expand their range of learning styles (Cekiso, 2011; Gilakjan, 2011; Hall, 2005;Robotham, 1999). As an awareness of learning styles can indicate areas that need attention, identifying students' learning styles could also support lecturers' efforts to develop appropriate teaching styles.

In order to create awareness of the existence of learning styles, the use of a learning styles assessment tool that helps students to identify and assess their own learning styles, is appropriate. Such a learning style assessment tool could raise awareness about similarities and differences in how students learn. The assessment of learning styles could provide students with an opportunity to be reflective, and could also encourage them to interrogate how they learn. This assessment should be done by using an effective learning styles assessment tool. To address this need, the Innovative Learning Experience (ILE) was adapted from the Centre Innovative for Teaching Experience (C.I.T.E.).

\section{Literature Review}

Students have different ways of engaging with their studies: by seeing; hearing; reflecting and acting; reasoning and intuition; analysing and visualising (Felder \& Spurling, 2005; Hill, Tomkinson, Hiley \& Dobson, 2014). These differences are often expressed in particular learning styles. It is important, therefore, for students to be able to identify and be aware of the different learning styles when engaging in the learning process.

Learning styles focus on how individuals process information, taking into account the role of cognitive and affective processes. Therefore, learning styles provide ways of supporting individuality in the learning process (Cekiso, 2011).Lecturers need to understand and embrace students' diversity by using different teaching approaches, depending on individual differences. 
Identifying and creating awareness of students' learning styles could assist students to gain confidence in their learning strengths, and develop strategies to confront difficult situations (Watson, 2003). Students can then take responsibility for their own learning. Lecturers' role should change to that of a guide in the learning process, rather than transmitters of knowledge (Bezuidenhout \& Alt, 2011; Van Rensburg, 2009).

Some studies caution against encouraging students to adopt a particular learning style, as students become 'intellectually short-sighted' and tend to avoid learning situations, which are not within their personal learning range (Robotham, 1999:6). A multimodal style of learning should be encouraged so that students may adjust to different teaching styles, and hence survive in different learning contexts.

A plethora of literature is devoted to the development of a number of instruments, which is designed to assess individual learning styles, including the Learning Style Inventory (Dunn, Dunn and Price, 1975; 1989), the Learning Style Inventory (Kolb, 1984;1985), the Learning Style Questionnaire (Honey \& Mumford, 1986;2000) and the Gregorc Style Delineator (Gregorc 1982). As a result, there are over 71 different learning styles models that describe learning styles (DeCapua \& Wintergerst, 2005; Hall \&Moseley, 2005). A number of educational psychologists provide evidence for the effectiveness of most learning style models, although some of the models are based on unconvincing theoretical grounds (Robotham, 1999).There is uncertainty around learning style instruments as far as construct validity is concerned (DeCapua \& Wintergerst, 2005: 2). All these learning style models assume that knowledge of learning differences in students could help them to understand how they learn and, consequently, enhance teaching and learning (Bacon, 2004; Cekiso, 2011; Genovese, 2004).

\section{Methodology}

The aim of this research was to develop a learning styles assessment tool, which is relevant for a higher education context. The question that this study tried to respond to was: What criteria can be used to develop a learning styles assessment tool that would be relevant for the higher education context? Further specific questions which guided the process were:

- What kind of instrument would be useful for higher education context? and

- What form could this tool take?

The objectives of this study were to examine existing learning styles theories, models and instruments in order to explore the possibility of using them as they were or by changing them. This article is based on a study which was for a doctoral thesis.

The data collection methodology that was used in the study was a mixed method approach, which comprised both qualitative and quantitative research methods. A non-probability, convenience sampling approach was employed for participant selection, with interviews, questionnaires and focus group discussion used as methods for data collection.

Learning style theories, instruments and models were examined. The learning style assessment instruments were analysed in to order determine the likelihood that they can be 
used as they are adapted or changed. The pertinence of each instrument was considered while a theoretical analysis of existing instruments was conducted in order to establish their uses, strengths, weaknesses and applicability within higher education. Criteria recommended by experts were taken into account and issues of simplicity, accessibility, and availability were also assessed. During analysis, the suitability of the instrument within a higher education context was considered as being centrally important.

As a result, eight learning styles models and instruments were explored while theoretical sampling was also used to collect and analyse data on existing learning style instruments.

Interviews were conducted with eight teaching and learning experts from four higher education institutions. The purpose of the interviews was to obtain recommendations from experts on the development of the learning styles assessment tool. The recommendations, which were proposed by experts informed the development of ILE. The recommendations by the experts were that the ILE should:

(i) be clear to students;

(ii) make students aware of the intricacies of the teaching and learning situation;

(iii) include a student voice; and

(iv) expose students to different learning styles.

They argued that ILE should expose students to various possibilities, especially those that encourage creativity. Hence, the ILE was shaped by the needs of the students.

The ILE was adapted from the C.I.T.E. model (Babich, Burdine, Allbright \&Randol, 1975). Robotham (1999) suggests that when assessing learning styles, one should use the most reliable instruments available that are available. Keeping the criteria that the experts proposed in mind, the C.I.T.E. model was adapted and changed in order to develop the ILE.

\section{Findings}

The findings of this study are discussed below; and some of the findings are supported by verbatim quotations from the study's participants.

\subsection{Exploration of existing instruments}

A theoretical analysis of existing instruments was conducted in order to establish their uses, strengths, weaknesses and applicability within higher education. Analysis of existing instruments was conducted in order to decide whether to develop an instrument from scratch, to adapt an instrument by making changes, or to use the instrument as it is. Not all existing instruments could be accessed owing to copyright and the high rates of payment. The criteria for analysis of the instruments included accessibility, availability, and simplicity of the language used, and being user-friendly to allow the users to identify their own learning styles.

Eight learning style models and instruments were explored. This included the Kolb Learning Style Inventory, the Honey and Mumford Learning Style Questionnaire, the Gregorc Style Delineator (GSD), the Felder and Silverman Index of Learning Styles, the Dunn and Dunn 
Learning Styles Model, the Vermunt Inventory of Learning Styles (VILS), the Grasha Reichmann Student Learning Styles Scales (GRSLSS) and the Center for Innovative Teaching Experiences (C.I.T.E.) learning styles assessment questionnaire.

Findings from the analysis of the existing learning style instruments revealed the different definitions of learning styles. However, certain assumptions about learning styles were drawn (Mkonto, 2010; 2015), and these assumptions include:

- Learning styles are personal and different;

- $\quad$ Learning styles are context driven;

- Learning styles involve information processing;

- Learning styles involve interacting with new information;

- Learning styles involve attitudes towards learning and the learning environment; and

- Learning styles are dynamic and depend on the task at hand.

\subsection{Development of a learning styles assessment tool}

The C.I.T.E. was found to be suitable for adaptation. The C.I.T.E. addresses the perceptual (visual, auditory, kinaesthetic and expressive) and social domains (social and individual group) (James \&Maher, 2004). This instrument consists of a questionnaire, is self-reporting, and can be scored manually. It is freely available and is relatively easy to complete. Only basic mathematical calculation skills were required in order to calculate their scores on the tool.

Making use of an available learning styles assessment instrument is advantageous, since it is cost saving and also saves time, which is required to create such an instrument from scratch (Van Rensburg, 2002). The C.I.T.E. was selected for adaptation for this study. The C.I.T.E. model has been used in various projects in the United States of America, especially amongst non-English speakers and students whose second language is English (ESL) (Reid, 1982; 1983; 1984). While the C.I.T.E. was used particularly in respect of the reasons outlined above, it does not suggest, nor is it trying to prove that only the C.I.T.E. instrument could be useful for first year students. Rather, it highlights that there is value in the analysis of learning styles in the process of teaching and learning within higher education.

The original C.I.T.E. consisted of a 40 sentence questionnaire only. In the Innovative Learning Experience (ILE), the sentence questionnaire was reduced to a 27- sentence questionnaire and consisted of a writing exercise. The reason for a reduction of sentence statements was that some statements were repetitive. The writing exercise required that students recall previous learning experiences, and identify those experiences that helped or hindered the effectiveness of their own learning. Kolb (1984) regards experience as being at the heart of the learning process. Allowing students to reflect on their previous learning experiences supports the idea that learning is not only concerned with cognition; it also involves thinking, feeling, perceiving and behaving (Hansman, 2001). The questionnaire 
created awareness about a variety of different approaches to learning. Some individuals had strong preferences for one or two learning styles; and others had more evenly balanced preferences, with no particular strong learning style preference.

The ILE evaluated three aspects: information gathering; work conditions; and expressiveness, which is the same as the original instrument. Expressiveness refers to the manner in which students feel comfortable with expressing themselves, which is either orally or by means of their writing skills. The statements in the questionnaire measured nine learning styles in the following areas: visual language; visual numerical; expressive written; expressive oral; social individual; social group; auditory language; auditory numerical; and kinaesthetic, which is also the same as in the original instrument. The original rating scale was retained. For each statement the user had to choose from a scale of 1 to 4 , with ranges 1 (strongly disagree), 2(disagree), 3 (agree), and 4 strongly agree.

In order to complete the ILE, the users had to indicate, by using the numerical values, whether the statements were strongly disagree (1), disagree (2), agree (3), and strongly agree (4). The total score was obtained by adding the numerical values, and the results were multiplied by 2 . The total scores identified whether the students had major, minor or negligible learning styles, which relate to that area. Instructions on how to use the learning styles instrument were provided in the tool, while explanations of the different learning styles were also provided. Therefore, the final version of the ILE consisted of three sections. Section A comprised the writing exercise, Section B comprised the questionnaire, and Section $\mathrm{C}$ comprised the learning style profile, where students could plot their learning styles.

The ILE has a number of limitations in its range, validity and reliability. ILE provides the user with a simple profile of their information gathering, work conditions, and expressiveness preferences. It does not take into consideration the context, engagement and motivation.

\subsection{The first piloting of the ILE}

The first pilot was conducted with 20 participants, including eight experts, three lecturers, six students, a statistician, a linguist and the research supervisor. The purpose of the first pilot was to determine the appropriateness of the ILE to assess learning styles. All the participants were given the ILE to complete. The students were required to complete the ILE in order to raise awareness and to identify their learning styles. Awareness of learning styles helps students to understand how they learn. This was confirmed by student comments such as:

The questionnaire helped me understand how I learn (A9); The questionnaire helps us as students to understand, evaluate and do introspection on our learning techniques (A6); It is interesting to see how a few questions can make your learning style more clear or known (A4); and The questionnaire was spot on and really spoke to me (A12).

Some students were even grateful for the opportunity to identify their learning styles, as indicated by the following comment:

Thank you very much for making me realize what learning styles suited me (A15). 
The ILE created awareness of students' learning styles. The students could identify their major, minor and negligible learning styles. This is an indication that awareness has been created.

The experts were given the learning style assessment tool to validate whether the ILE was developed based on their recommendations. They offered the following as one of their comments:

I believe the tool has the potential to have positive influence on learning and teaching in higher education institutions (E3).

The lecturers were given the tool to assess whether the learning styles assessment tool would be suitable for use by students.

This tool will help the students understand their learning patterns (L8).

The lecturers also highlighted the benefits of the tool beyond the classroom:

The tool could solve the challenges faced by the education context of seeking remedial measures in order to improve the quality of graduates (L5).

The lecturers also highlighted the importance of knowledge of students' learning styles by the lecturers:

Both students and lecturers will be aware of different learning types (L1);

Knowing of students' learning styles will allow lecturers to facilitate learning and thinking in class (L2);

Lecturers could adapt their teaching styles to suit the students' learning styles and therefore make teaching and learning more effective (L7); and

Knowing students' learning styles will allow lecturers to fill gaps and work on developing other styles, which may be more appropriate in higher education context (L4).

The linguist was given the learning styles assessment tool in order to check the clarity of the language that is used in the ILE. Reid (1987) argues that sometimes the language used in learning styles is not easy to understand. The statistician was given the tool to ensure that the statements were evenly distributed, and that the scoring was accurate. All the participants confirmed the appropriateness of the ILE. The participants also suggested some changes, which were affected before the second actual pilot took place.

\subsection{The second pilot of the ILE}

The second pilot was conducted with 130 first year students in six faculties at an institution of higher education. The students had to write about their past learning experiences before completing the self-scoring learning assessment questionnaire. The aim of the writing exercise was for the students to individually reflect on their past learning experiences, while the aim of the self-scoring learning styles questionnaire was to assess the students' learning styles in order to identify their dominant learning styles. A study which was conducted by 


\section{Macrothink}

Reid (1987) with post-secondary school students in Colorado to identify their learning styles preferences by using a self-reporting questionnaire indicates that students preferred learning styles that were related to their learning strengths. The learning styles, which emerged in the questionnaire, were confirmed in the writing exercise.

The survey results that showed that the student has social individual as their major learning style in the questionnaire, in the writing exercise wrote:

I like studying alone and look at myself in the mirror (A9); and

I study alone and hate it when people are around because I get distracted (A6).

The survey results that showed that the student has kinaesthetic tactile as their major learning style in the questionnaire, in the writing exercise commented:

I like to do something physically in order to learn it (A17);

I like to make and touch things (A11); and

I like to learn through experiences (A12).

The survey results that showed that the student has social group as their major learning style in the questionnaire, in the writing exercise wrote:

I like working with other students, learning with others makes us understand an issue better because we discuss it and listen to others' views (A20); and

I do not work on my own very well (A1).

The survey results that showed that the student has visual language and visual numerical as their major learning styles in the writing exercise they wrote:

I study better when I see things are written down (A8);

I study better when I write down notes (A5); and

I write down numbers before I can add them (A3);

The survey results that showed that the student has auditory numerical and auditory language as their major learning styles, commented as follows:

When I am given numbers I can add them in my head without writing them down I am good with number (A3);

I like to listen to lecturer teaching and can understand better than learning on my own (A15); and

Listening to a recorded lecture rather than reading notes works for me (A5)

The survey results that showed that the student has expressive oral and expressive written as their major learning styles in the questionnaire, in the written exercise they wrote comments such as: 
I wish tests could be done orally (A11); and

In written assignments I score more marks (A3).

\section{Discussion}

The ILE not only gave students an understanding of their learning styles, but also provided a variety of learning styles to choose from. The literature that was consulted for this study shows that students who are aware of their learning styles can identify their own strengths and weaknesses with regards to learning (Cekiso, 2011; Gilakjan, 2011; Mkonto, 2015). As much as the ILE gives an indication about learning strengths and weaknesses, it also helps to identify areas that need attention. Students should, therefore, be supported in their preferred way of learning, and be further challenged to expand their learning styles. Learners can take ownership of their learning once they are made aware of the factors, which promote learning (Gilakjan, 2011; Robotham, 1999).This study enabled students in a higher education institution to become aware of and identify their learning styles.

It is often assumed that a learning style assessment instrument can measure how students learn by using a questionnaire alone (Smith, 2002). The ILE deliberately allowed students to reflect and to express themselves in the writing exercise, where they could give an account of their past learning experiences. Participating in reflective writing contributes to self-directed learning (Robotham, 1995). This involves improvement of learning styles attributes and the selection of learning activities, which maximise learning (Van Rensburg, 2009). The students wrote about how they learnt, what hindered their learning, their perceived strengths and weaknesses in learning, and how they believed they could improve their learning. Hence, they were given a "voice".

Cuthberts (2005) argues that students' prior learning experiences could have an impact on how they learn. These experiences are particularly relevant for the learning process. The students were afforded an opportunity to interrogate how they learn in the form of a writing exercise, which provided them with an opportunity to reflect about their past learning experiences. In some cases the students not only wrote about their learning experiences, but also reflected on other challenges that had impacted on their learning such as finances, accommodation and lack of support from home.

The findings from both the first pilot and the second pilot revealed that the students had individual and different learning styles. This supports the view that learning styles acknowledge the uniqueness of students in the learning process.

\section{Implication to research and practice}

An implication of this study is that the ILE can be used to promote more effective teaching and learning in a higher education context. Students should be encouraged to reflect on and question their own learning practices. Lecturers could use students' learning differences and strengths as a basis to prepare their lectures. 


\section{Conclusion}

Literature acknowledges the existence of learning styles and supports the assessment of students' learning style preferences. The ILE allows students to express themselves in their own voice, and to reflect on their learning experiences for the benefit of all concerned. Creating awareness about learning styles and the assessment of learning styles promote self-directed learning. This encompasses students'- knowing their strengths and weaknesses with regards to learning and consciously selecting activities that will maximize learning. Students should assess and identify their learning differences in order to cope with the demands of higher education. Use of a simple, accessible, affordable and user-friendly learning style assessment tool at higher education level is, therefore, highly recommended.

Lecturers should to engage in dialogue with their students in order to make teaching and learning meaningful both for themselves and the students. With the changes taking place in higher education institutions, increasing demands are placed on students for enhanced academic performance.

It is hoped that this article will empower students to understand how they learn, and to become effective and independent students. It is also trusted that this article will help lecturers to understand their students' learning styles and to devise strategies, which support student learning.

\section{Future Research}

Future research which involves using the ILE with students in different countries, can and should be conducted.

\section{References}

Bacon, D.R. (2004). An examination of two Learning styles measures and their association with business learning. Journal of Education of Business 79(4), 205-209. http://dx.doi.org/10.3200/JOEB.79.4.205-208

Babich, A.M., Burdine, P., Allbright, L., \& Randol, P. (1975). Center for Innovative Teaching Experiences Learning styles instrument. Wichita: Murdock Teacher Center.

Biggs, J.B. (1987). Student Approaches to Learning and Studying. Research Monograph. Hawthorn: Australian Council for Education Research.

Biggs, J.B. (2003). Teaching for Quality Learning at University. Great Britain: Cromwell Press.

Boström, L. (2011). Students' learning styles compared with their teachers' learning styles in secondary schools. Institute for Learning Styles Journal, 1, 17-38.

Bowles, T. (2004). Adult approaches to learning and associated talents. Australian Journal of Education and Development Psychology, 4, 1-12.

Cassidy, S. (2004). Learning styles: An overview of theories, models and measures. Educational Psychology, 24(4), 419-444. http://dx.doi.org/10.1080/0144341042000228834

Cassidy, S. (2008). Approaches to learning and competitive attitude in students interested in the health professions. Journal of Applied Physiology Online, 33,30-36. 
Cekiso, M.P. (2011). Profiling learning style preferences of first-year University students: Implications for course design and instruction. South African Journal of Higher Education, 25(7), 1288-1309.

Cuthberts, P.F. (2005). Student learning Process: Learning styles or learning approaches? Teaching in Higher Education, 10(2), 235-249. http://dx.doi.org/10.1080/1356251042000337972

DeCapua, A., \& Wintergerst, A.C. (2005). Assessing and validating a learning styles instrument. System, 33, 1-16. http://dx.doi.org/10.1016/j.system.2004.10.003

Dunn, R., Dunn, K., \& Price, G. (1975). The learning Style Inventory. Price Systems, Lawrence, KS.

Dunn, R., \& Griggs, S.A. (2000). Practical Approaches to using learning styles in higher education. Westport CT: Bergin and Garvey.

Dunn, R., Deckinger, L., Withers, P., \& Katzenstein, H. (1990). Should college students be taught how to do homework? Illinois Research and Development Journal, 26(2), 96-11.

Du Plessis, A., Muller, H., \& Prinsloo, P. (2007). Validating the profile of a successful first-year accounting student. The South African Journal of Higher Education, 19(4), 684-698.

Felder, R.M., \& Spurlin, J.E. (2005). Application, reliability, and validity of the Index of Learning Style, A validation study of the Index of Learning Styles. International Journal of Engineering Education, 21(1), 103-112.

Fraser, W.J., \& Killen, L.R. (2003). Factors influencing academic success or failure of first year and senior university students: Do education students and lecturers perceive things differently? South African Journal of Education, 2(4), 254-260.

Fritz, M. (2002). Using learning styles inventory to promote active learning. Journal of College Reading and Learning, 32, 183-188. http://dx.doi.org/10.1080/10790195.2002.10850297

Genovese, J.E.C. (2004). The Index of Learning Styles: An investigation of its reliability and concurrent validity with preference test. Individual Differences Research, 2(3), 169-174.

Gould, T.E., \& Caswell, S.V. (2006). Stylist learning differences between undergraduate athletic training students and educators: Gregorc Mind Styles. Journal of Athletic Training, 41(1), 109-117.

Gregorc, A. (1982). Gregorc Style Delineator. Gabriel Systems, Mynard, MA.

Hansman, C.A. (2001). Context-based adult learning. In the new update learning, ed. S. Merriam, New Directions for Adult and Continuing Education, 89, 43-51. San Francisco: JosseyBass. http://dx.doi.org/10.1002/ace.7

Hall, E. (2005). Learning styles- Is there evidence based for this popular idea? Education Review, 19, 49-56.

Hall, E., \& Moseley, D. (2005). Is there a role for learning styles in personalized education and training? International Journal of Lifelong Education, 24, 243-255. http://dx.doi.org/10.1080/02601370500134933 
Hay, H.R., \& Marais, F. (2004). Bridging programmes: gain, pain or all in vain. South African Journal of Higher Education, 18, 59-75. http://dx.doi.org/10.4314/sajhe.v18i2.25454

Hill, F., Tomkinson, B., Hiley, A, \& Dobson, H. (2014). Learning styles preferences: An examination of differences amongst students with different disciplinary backgrounds. Innovations in Education and Teaching International, 1-14, http://dx.doi.org/10.1080/14703297.2014.961504

James, W.B., \& Maher, P.A. (2004). Understanding and using learning styles. In: Galbraith M.W. (ed.), Adult learning methods: A guide to effective instruction (3rd Ed.). Malabar, FL: Krieger.

Kolb, D.A. (1984). The experiential learning: Experience as a resource of learning and development. Englewood Cliffs: Prentice Hall.

Kolb, D.A. (1985). Learning style inventory. Boston MA: McBer and Company.

Kolb, A.Y., \& Kolb, D.A. (2005). Learning styles and learning spaces: Enhancing experiential learning in higher education. Academy of Management Learning and Education, 4(2), 193-212. http://dx.doi.org/10.5465/AMLE.2005.17268566

Levett-Jones, T. (2005). Self-directed learning: Implications and limitations for undergraduate nursing education. Nurse Education Today, 25(5), 363-368. http://dx.doi.org/10.1016/j.nedt.2005.03.003

Loots, A.G.J. (2009). Student involvement and retention in higher education: The case for academic peer mentoring programmes for first-years. Education as Change, 13(1), 211-235. http://dx.doi.org/10.1080/16823200902945077

Merriam, S.B. (2001). Adult learning: Where have we come from? Where are we headed? New Directions for Adult and Continuing Education Series, no 89. San Francisco: Jossey Bass.

Mkonto, P.N. (2010). The development and evaluation of a learning styles assessment tool for the South African higher education context. Unpublished Ph.D. thesis. University of the Western Cape.

Mkonto, N. (2015). Students' Learning Preferences. Journal of Education Studies, 5(3), 211-235. http://dx.doi.org/10.5296/jse.v15i3.8125

Mulalic, A.M., Shaw, M., \& Ahmad, F. (2009). Perceptual learning styles of ESL, 7(3), 101-103.

Reid, J.M. (1982). Perceptual learning styles preferences of international students. Paper presented at the Colorado Teachers of English to Speakers of Other Languages (CoTESOL) Conference: Denver.

Reid, J.M. (1983). Perceptual learning styles of international students. Paper presented at the National NAFSA Conference: Baltimore.

Reid, J.M. (1987). The learning styles preferences of English as a second language (ESL) students. Teachers of English to Speakers of Other Languages (TESOL) Quarterly, 21(1), 87-111.

Reid, J.M. (1990). The dirty laundry of ESL survey research. Teachers of English to Speakers of Other Languages (TESOL) Quarterly, 24(2), 323-338. http://dx.doi.org/10.2307/3586913 


\section{Macrothink}

Journal of Studies in Education

ISSN 2162-6952 2016, Vol. 6, No. 2

Robotham, D. (1995). Self-directed learning: The ultimate learning style? Journal of European Industrial Training, 19(7), 3-7. http://dx.doi.org/10.1108/03090599510092918

Robotham, D. (1999). The application of learning style theory in higher education teaching. http://www2.glos.ac.uk/GDN/discuss/kolb2.htm accessed 17/09/12.

Smith, J. (2002). Learning Styles: Fashion fad or lever for change? The application of learning styles theories to inclusive curriculum delivery. Innovation and Teaching International, 39, 63-70. http://dx.doi.org/10.1080/13558000110102913

Van Rensburg, G.H. (2002). Learning styles: Implications for higher education. Unpublished Ph.D thesis. University of South Africa.

Van Rensburg, G.H. (2009). The development of a self-assessment learning style instrument for higher education. South African Journal of Higher Education, 23(1), 179-191. http://dx.doi.org/10.4314/sajhe.v23i1.44814

Vermunt, J.D. (1996). Metacognitive, cognitive and affective aspects of learning styles and strategies: A phenomenographic analysis. Higher Education, 31, 25-50. http://dx.doi.org/10.1007/BF00129106

Watson, S.A. (2003). Implementing learning styles into the design classroom. Journal of Design Communication Issue, 5, 1-7. 


\section{PART 1}

\section{THE WRITING EXERCISE}

NAME

COURSE

YEAR OF STUDY

DATE

Write a short account of your past learning experiences, how you learn, mentioning strengths and weaknesses in learning and how these have made you learn effectively. 
PART 2

THE LEARNING STYLES QUESTIONNAIRE AND SCORING SHEET

NAME

CLASS

DATE

Instructions: There are four responses for each statement. Each response has a numerical value. Read the each statement and decide which of the four responsesdo you strongly agree (4), agree (3), disagree (2) and strongly disagree (1). Put an $X$ on the number of your response.

\begin{tabular}{|l|l|l|l|l|}
\hline \multicolumn{1}{|c|}{ Statements } & \multicolumn{1}{|c|}{$\begin{array}{c}\text { Strongly } \\
\text { agree }\end{array}$} & Agree & Disagree & \multicolumn{1}{|c|}{$\begin{array}{l}\text { Strongly } \\
\text { disagree }\end{array}$} \\
\hline $\begin{array}{l}\text { 1. When I am involved in } \\
\text { practical work, I remember } \\
\text { what I have learnt better. }\end{array}$ & 4 & 3 & 2 & 1 \\
\hline $\begin{array}{l}\text { 2. I enjoy doing written } \\
\text { assignments }\end{array}$ & 4 & 3 & 2 & 1 \\
\hline $\begin{array}{l}\text { 3. I learn better when I listen } \\
\text { in a lecture than when I } \\
\text { study on my own. }\end{array}$ & 4 & 3 & 2 & 1 \\
\hline $\begin{array}{l}\text { 4. I learn best when I study } \\
\text { alone. }\end{array}$ & 4 & 3 & 2 & 1 \\
\hline $\begin{array}{l}\text { 5. Having clear instructions } \\
\text { on how to do an assignment } \\
\text { makes it easier to } \\
\text { understand. }\end{array}$ & 3 & 3 & 2 & 1 \\
\hline $\begin{array}{l}\text { 6. I would rather do an oral } \\
\text { presentation than write an } \\
\text { assignment }\end{array}$ & 4 & 2 & 1 \\
\hline $\begin{array}{l}\text { 7. I can solve maths } \\
\text { problems without writing }\end{array}$ & 4 & 3 & 2 & 1 \\
\hline
\end{tabular}




\begin{tabular}{|c|c|c|c|c|}
\hline them down. & & & & \\
\hline $\begin{array}{l}\text { 8. If I need help in the } \\
\text { subject, I ask a classmate for } \\
\text { help. }\end{array}$ & 4 & 3 & 2 & 1 \\
\hline $\begin{array}{l}\text { 9. I understand maths better } \\
\text { when I see the numbers } \\
\text { written down. }\end{array}$ & 4 & 3 & 2 & 1 \\
\hline $\begin{array}{l}\text { 10. I would rather write an } \\
\text { assignment than be involved } \\
\text { in discussion. }\end{array}$ & 4 & 3 & 2 & 1 \\
\hline $\begin{array}{l}\text { 11. I remember things I } \\
\text { heard better than things I } \\
\text { have read. }\end{array}$ & 4 & 3 & 2 & 1 \\
\hline $\begin{array}{l}\text { 12. I remember more of } \\
\text { what I learn if I learn it } \\
\text { when I am alone. }\end{array}$ & 4 & 3 & 2 & 1 \\
\hline $\begin{array}{l}\text { 13. I would rather read a } \\
\text { book myself than listen to } \\
\text { somebody reading to me. }\end{array}$ & 4 & 3 & 2 & 1 \\
\hline $\begin{array}{l}\text { 14. I engage more in } \\
\text { discussions than writing on } \\
\text { my own. }\end{array}$ & 4 & 3 & 2 & 1 \\
\hline $\begin{array}{l}\text { 15. I work better with } \\
\text { numbers when they are } \\
\text { given to me orally. }\end{array}$ & 4 & 3 & 2 & 1 \\
\hline $\begin{array}{l}\text { 16. I like to work in a group } \\
\text { because I learn from others } \\
\text { in the group. }\end{array}$ & 4 & 3 & 2 & 1 \\
\hline $\begin{array}{l}\text { 17. Written maths problems } \\
\text { are easier for me to do than } \\
\text { the ones given orally. }\end{array}$ & 4 & 3 & 2 & 1 \\
\hline $\begin{array}{l}\text { 18. Drawing something help } \\
\text { me understand it better. }\end{array}$ & 4 & 3 & 2 & 1 \\
\hline $\begin{array}{l}\text { 19. It is easier for me to } \\
\text { understand what I have read }\end{array}$ & 4 & 3 & 2 & 1 \\
\hline
\end{tabular}




\begin{tabular}{|c|c|c|c|c|}
\hline than what I have heard. & & & & \\
\hline $\begin{array}{l}\text { 20. When I work on an } \\
\text { assignment I like working } \\
\text { alone. }\end{array}$ & & & & \\
\hline $\begin{array}{l}21 . \text { I prefer to be given } \\
\text { written directions than } \\
\text { spoken ones. }\end{array}$ & 4 & 3 & 2 & 1 \\
\hline $\begin{array}{l}\text { 22. I prefer oral } \\
\text { tests/examination to written } \\
\text { ones. }\end{array}$ & 4 & 3 & 2 & 1 \\
\hline $\begin{array}{l}\text { 23. I remember numbers for } \\
\text { long without writing them } \\
\text { down. }\end{array}$ & 4 & 3 & 2 & 1 \\
\hline $\begin{array}{l}\text { 24. I get more work done } \\
\text { when I work with others. }\end{array}$ & 4 & 3 & 2 & 1 \\
\hline $\begin{array}{l}25 . \text { When I see numbers it } \\
\text { makes it easier for me to } \\
\text { work with them. }\end{array}$ & 4 & 3 & 2 & 1 \\
\hline $\begin{array}{l}\text { 26. I like projects where I } \\
\text { have to make things with } \\
\text { my hands. }\end{array}$ & 4 & 3 & 2 & 1 \\
\hline $\begin{array}{l}\text { 27. I prefer written tests to } \\
\text { oral tests. }\end{array}$ & 4 & 3 & 2 & 1 \\
\hline
\end{tabular}




\section{SCORE SHEET}

Directions: Find the statement number on the Learning Style Inventory and write the number (1-4) on the blank spaces. Total the numbers under each heading. Multiply the heading by two. Look at the scores to decide on the dominant learning style.

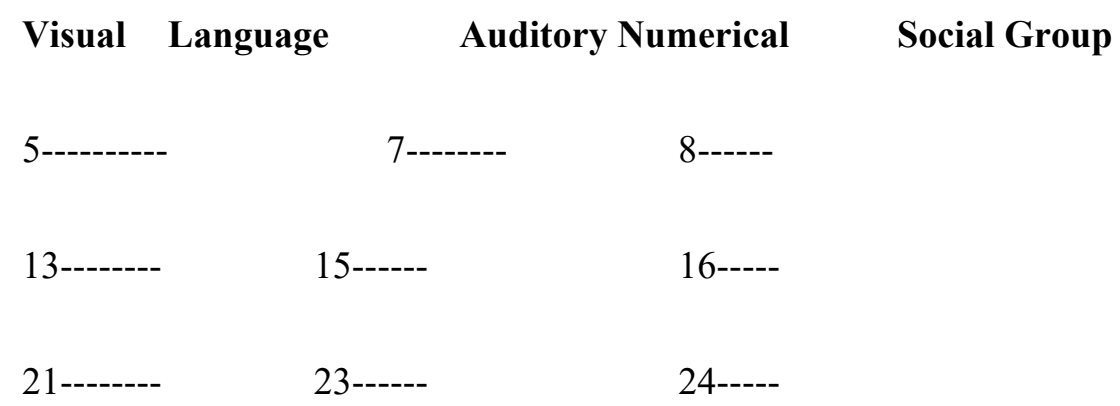

Total ....... $2=\quad$ Total .......x2 $=\quad$ Total ......x2

Visual Numerical Kinesthetic- Tactile Expressiveness Oral

$\begin{array}{lll}9 \text {----- } & 1 \text {----- } & 6 \text {------- } \\ 17---- & 18---- & 14----- \\ 25---- & 26---- & 22-----\end{array}$

Total ......x2 =------ $\quad$ Total .....x2 =------ $\quad$ Total ......x2 =-------

Auditory Language Social Individual Expressiveness-Written

3 ------ $\quad 4$ 4------ $\quad$ 2---

$11-----\quad 12----$

19----- 20 20------

Total.....x2 =------- $\quad$ Total....x2 =------ $\quad$ Total .....x2 =--------

Score: $21-27=$ Major Learning Style - You prefer this learning style and feel comfortable using it. 
Score: $12-18=$ Minor Learning Style - You use this style of learning, but usually as a second choice or in conjunction with other learning styles.

Score: $\quad 6-9=$ Negligible use - You prefer not to use this learning style.

\section{Learning Styles Explanations}

\begin{tabular}{|c|c|}
\hline Learning styles & Explanation \\
\hline Auditory language & $\begin{array}{l}\text { These students learn best from hearing } \\
\text { information presented to them. }\end{array}$ \\
\hline Visual language & $\begin{array}{l}\text { These students learn best seeing the } \\
\text { information presented to them. }\end{array}$ \\
\hline Auditory numerical & $\begin{array}{l}\text { These students learn best from hearing } \\
\text { numbers. }\end{array}$ \\
\hline Visual numerical & $\begin{array}{l}\text { These students learn best by seeing } \\
\text { numbers. }\end{array}$ \\
\hline Kinaesthetic tactile & These students learn best by being involved. \\
\hline Social individual & These students like to study alone. \\
\hline Social group & These students learn best when in a group. \\
\hline Expressive oral & $\begin{array}{l}\text { These students learn best when they can } \\
\text { express themselves orally. }\end{array}$ \\
\hline Expressive written & $\begin{array}{l}\text { These students learn best when they express } \\
\text { themselves in written form. }\end{array}$ \\
\hline
\end{tabular}

